\title{
The Impact of Labov's Contribution to general Linguistic Theory
}

Gregersen, Frans; Cornips, Leonie

Published in:

Journal of Sociolinguistics

Publication date:

2016

Document version

Publisher's PDF, also known as Version of record

Citation for published version (APA):

Gregersen, F., \& Cornips, L. (2016). The Impact of Labov's Contribution to general Linguistic Theory. Journal of Sociolinguistics, 20(4), 498-524. 


\title{
The impact of Labov's contribution to general linguistic theory
}

\section{Leonie Cornips and Frans Gregersen}

Meertens Instituut and Maastricht University, The Netherlands, and the LANCHART Centre, University of Copenhagen, Denmark

\begin{abstract}
The paper first discusses the influence of Labov on certain recent Chomskyan developments, starting from an identification of two radically different readings of the relationship between Labovian variationist sociolinguistics and the dominant theoretical paradigm of the latter half of the 20th century which is Chomskyan theoretical linguistics, i.e. as either a supplement or an alternative. Variation at the level of closely related languages, at the level of the language community, and at the level of the individual, have all been treated by Chomskyans under various headings, thus giving evidence that empirical results stemming from variationist sociolinguistics cannot be ignored. However, the treatment has not led to an integration of variation into Chomskyan theory, nor could it. In the final section we outline what a Labovian materialist alternative to Chomskyan idealism could be. We argue that this calls for a broader definition of sociolinguistics than just variationism and poses demands for both internal integration, viz. of linguistic disciplines, and external integration of the language sciences with evolutionary psychology, anthropology and social history.
\end{abstract}

Dit artikel bespreekt de invloed van de Laboviaanse variationistische sociolinguïstiek op de Chomskyaanse generatieve grammatica als het dominante theoretische paradigma in de laatste helft van de 20e eeuw. We identificeren eerst twee radicaal verschillende lezingen die tussen beide disciplines mogelijk zijn, namelijk of de variationistische sociolinguïstiek een aanvulling of een alternatief is op de generatieve grammatica. De generatieve grammatica bestudeert op dit moment variatie op het niveau tussen taalvariëteiten die typologisch gezien minimaal van elkaar verschillen, variatie op het niveau van de taalgemeenschap en op het niveau van het individu en toont daarmee dat empirische data uit de sociolinguïstiek niet langer te negeren zijn. Desondanks leidt de analyse van empirische data niet tot een integratie tussen de variationistische sociolinguïstiek en de generatieve grammatica en dit is volgens ons ook niet mogelijk. In de laatste sectie presenteren we wel hoe een Laboviaans materialistisch alternatief op het Chomskyaanse idealisme eruit zou kunnen zien. We beargumenteren dat een bredere definitie van de sociolinguïstiek dan alleen de variationistische sociolinguïstiek nodig is en stellen een interne integratie voor van linguïstische disciplines en 
externe integratie van de taalwetenschappen waaronder evolutionaire psychologie, antropologie en sociale geschiedenis. [Dutch]

KEYWORDS: Variationist sociolinguistics, materialist vs. idealist perspectives and approaches, models of level of data and theory, sociolinguistic variable, linguistic fact, micro-variation, methodologies, empirification of generative grammar, integrated theory of language

\section{INTRODUCTION}

Our assignment is this: what is Labov's contribution to general linguistic theory and how has he influenced the theoretical character of linguistics as a whole? In this question, the notion 'general linguistic theory' is not selfexplanatory. ${ }^{1}$ Thus, we must begin by explaining in what sense Labov has contributed to what kind of theory.

A general linguistic theory may be taken to consist of at least the following elements (Gregersen and Køppe 1988): a stance as to what ontological status the object of enquiry - in this case language - has, and a set of assumptions and assertions leading from that to:

- a delimitation of the field of enquiry, thus characterizing possible types of data;

- a specification of the central questions to be answered or issues to be investigated; and

- a characterization of the methods favored in addressing the issues scientifically.

Any specification of method and data implies a stance on the theory of science, viz. what is recognized as valid ways of doing research on language.

From this perspective, what William Labov has contributed is a set of generalizations and insights firmly based on data collected and analyzed by methods developed by Labov himself - albeit based on prior developments within dialectology and anthropology - into how language changes; in particular, sound change. Labov was encouraged by Uriel Weinreich as his doctoral supervisor 'to apply the tools of linguistics to the language of every-day life, and to set aside the barriers between linguistic analysis and dialectology' (Labov 1998: 111). The paradigmatic nature of Labov's first foundational work, i.e. The Social Stratification of Language in New York City (1966), is obvious. Suffice it to say that establishing a firm empirical basis for a theory of sound change, for so long the province of historical linguistics (always focused on written materials from distant epochs) and/or dialectology (always primarily concerned with rural speech), is a significant achievement in and of itself.

But is that all we should ask from a general linguistic theory, i.e. a theory of language? Surely not. At this point, it may be helpful to introduce the 
Table 1: Seven levels of data and theory (reworked from Gregersen 2000)

\begin{tabular}{ll}
\hline Level & Description \\
\hline 1. RAW DATA & $\begin{array}{l}\text { Sensory input, e.g. sounds. } \\
\text { Theory laden percepts, e.g. elements of a phonetic (IPA) } \\
\text { transcription. }\end{array}$ \\
3. THEORY 1 & $\begin{array}{l}\text { Ordering of theory laden percepts from a specific point of view, } \\
\text { e.g. a phonological analysis. }\end{array}$ \\
4. THEORY 2 & $\begin{array}{l}\text { Discipline specific theory, e.g. a sociolinguistic theory of language } \\
\text { change. }\end{array}$ \\
5. THEORY 3 & $\begin{array}{l}\text { Superordinate, but still object specific, theory, e.g. a structuralist } \\
\text { theory of language. }\end{array}$ \\
6. THEORY 4 & $\begin{array}{l}\text { Interdisciplinary theories valid for a whole field, e.g. a structuralist } \\
\text { theory for all of the human sciences. }\end{array}$ \\
7. THEORY 5 & $\begin{array}{l}\text { World view formulated using traditional dichotomies, e.g. } \\
\text { materialism vs. idealism; rationalism vs. romanticism; etc. }\end{array}$ \\
\hline
\end{tabular}

seven-layered model of the levels of data and theory, illustrated in Table 1, which the second author collaborated with Simo Køppe in developing years ago for other purposes (Gregersen 2000). In an ideal world, a theory would be consistent on all levels - a materialist theory of language would delimit a different field of study to an idealist one. Briefly, a materialist theory would open the field of linguistics such that any statements on language should, in principle, comply with 'known facts' from e.g. neurology, memory research and other cognitive psychological insights on the one hand, and with 'known facts' from sociology and history on the other. Idealism would, in contrast, favor the autonomy thesis so influential since Saussure, i.e. that language, as such, is a decontextualized separate structure. Issues raised as desiderata to be addressed would also differ profoundly: whereas idealism is connected to the individual (grammar) and takes ideas (or abstract language structures) to be the leading driving forces in history, materialism takes the contradictions between the forces of production and social structures to be the essential conditions for change, including - in this case - language change (we will come back to this in section 6).

\subsection{Labovian (variationist) sociolinguistics and Chomskyan generative linguistics}

We will, below, investigate how Labov's contribution - fleshing out a materialist perspective on language - has interacted with Chomskyan idealist linguistic theory. There are several reasons to focus on Chomskyan theory as the general linguistic theory to be discussed in this paper. First, instead of presenting - forced by the word limits of this paper - a brief and necessarily superficial view on convergence, divergence and connections between sociolinguistics and all other linguistic theories possible, we choose instead 
to detail the relationships to the one linguistic theory that universally is considered to be the most influential of the latter half of the 20th century. Second, if William Labov (2002) took a stance on other linguistic theories, he most often, if not always, positioned himself towards Chomskyan linguistics from the perspective of variationist sociolinguistics. Last, but not least, the first invited author is a syntactician who has worked extensively within both the Chomskyan and the Labovian paradigm.

The paper will deal mainly with variationist sociolinguistics since we will argue that Labov's theory and practice has had a major effect on work in syntactic theory, through the development of methodologies focused on microvariation. The final section, however, will elaborate on the need for a broader and more encompassing sociolinguistic theory including parts of the field which may not be seen as variationist by any standard, even types of linguistics which are not seen as sociolinguistics at all.

Our point of departure has repercussions for the view taken in this paper on how to answer the introductory question as to William Labov's influence. We are left with two alternatives:

The idealist approach is exemplified by generative grammar, as originated and developed by Chomsky $(1957,1965)(. .$.$) . The materialist position is exemplified by$ the practice current in phonetics, historical linguistics, and dialectology. The principles of this position have been developed most explicitly in sociolinguistics, and in particular in the quantitative study of linguistic variation (...). (Labov 1987)

Thus, one choice is siding with the two alternatives and Labov's revolutionary view on it:

The two approaches, idealist and materialist, differ sharply in their approaches to the foundations of the field: definition of language itself, the methods for gathering data and analyzing it, and the goals of linguistic activity. (Labov 1987)

This would lead to the elaboration of sociolinguistics as an alternative to Chomskyan theory, viz. a materialist alternative to the idealism admittedly characteristic of Chomskyan theorizing. However, the more appealing alternative from the point of view of Labov's influence outside his own field, i.e. on theoretical linguistics, is rather to side with the ecumenical stance taken by Labov in a number of more recent papers. Here, Labov voiced the notion that the materialist and idealist approach each contribute to an understanding of the general phenomenon of human language, as follows:

Among the paths that linguists follow in pursuit of a better understanding of human language, we can trace two main branches.

THE SEARCH FOR UNIVERSAL GRAMMAR $[\ldots]$

UNDERSTANDING LANGUAGE CHANGE. (Labov 2012: 4)

Even more recently, he expressed this in a clip from an interview with Sali Tagliamonte: 
There's only one serious mistake you can make in Linguistics, which is fatal and once you've made it, you're finished. Sali: What's that? Bill: To think that Chomsky's the problem. If you get rid of Chomsky you've suddenly solved something. (Tagliamonte 2015: 81)

Accordingly, the train of thought in this paper is as follows. We first explain why there was indeed no alternative to Chomsky as a theoretician and detail the Labovian stance on data and methodology. Then we tell the story of how Labovian insights and methods have gradually seeped into Chomskyan theorizing and - primarily - practices. It started with accounting for variation between languages attempting to elaborate on the Universal Grammar hypothesis. This initial comparison between whole languages, viewed essentially as abstractions of individual grammars, developed into the micro-syntactic enterprise of comparing minimal differences between typologically closely related languages and finally to differences within a language (dialect differences) and eventually to intra-individual variation. This is, then, a story about how the central Labovian notion of variation has made its way into mainstream theoretical linguistics: Labov's contribution, both his ideas on (1) how to elicit dialect data, i.e. data that are normally excluded from (national) standard languages, and (2) the sociolinguistic variationist knowledge about minimal dialect differences within a language, have, as we show, been an inspiration to those working in syntactic microvariation research. Our story details how the study of Labovian variation challenged received wisdom as to what linguistic facts are and which conception of the individual's grammar should be the point of departure for solid empirical work. The story might also be phrased as the gradual empirification of armchair linguistics under the pressure of linguistic evidence.

The issues which Labov $(1972,1975,1984,1996)$ has himself brought to general linguistic theory in his discussions with the Chomskyans were and are:

1. The definition of a linguistic fact.

2. The methods for gathering data.

3. The theoretical instantiation of inter- and intra-individual variation.

This paper will be structured around these three topics, where the idealist and materialist positions differ most profoundly, until the end when it takes up the challenge of being more explicit about what a general materialist alternative would look like (see section 6).

\section{THE ORIGINAL LANDSCAPE OF LABOVIAN SOCIOLINGUISTICS: BACK TO THE 60s}

In this section, we will address the question of why Labov did not develop an alternative linguistics since his intent never was to create a sociolinguistics. 
The pedigree of variationist sociolinguistics has been explicitly laid out first and foremost in the programmatic 1968 paper by Weinreich, Labov and Herzog. In this paper, Hermann Paul is treated as the only opponent worthy of thorough discussion. It is noteworthy that Weinreich (who wrote the first section) dismissed Saussure as irrelevant although he himself might be placed directly in the line of succession from Saussure to Meillet and on to Martinet who was Weinreich's doctoral supervisor. Martinet even wrote the important preface to Weinreich's celebrated Languages in Contact (Weinreich 1953 [1967]).

The choice of the Neogrammarian Hermann Paul as the favorite ancestor is, however, not accidental. The inheritance from the Neogrammarians includes:

- the interest in language change;

- the empirical slant of their approach to theorization and, consequently;

- the obligation to search for possible generalizations.

In addition, Neogrammarian historical linguistics was the first scientific linguistics to be introduced to the U.S.A. and, thus, has formed the background for every succeeding wave of theory. In the early 20th century, historical linguistics was replaced by structural linguistics as the main current in American linguistics through the work of the Bloomfield generation (Hymes and Fought 1981). In contrast to European structuralism, the American current of the same name was mainly descriptive, inductive and behaviorist. So when the so-called Chomskyan revolution discarded structuralist thinking in general and so to speak turned American structuralism on its head, favoring a deductive, theoretical approach and model building instead of description (Ruwet 1968), the only niche left for sociolinguistics in the family of American linguistics was that of an empirical synchronic study of language change. By synchronic we mean dynamic, hence the apparent time model of linguistic change. The methods adopted were taken from anthropology and dialectology, and were combined to result in a detailed prescription for field work (Labov 1984) leading to spoken language data replete with variation. This was the challenge for early sociolinguistics, and we argue it still is: how do we account for the various kinds of variation between speakers (interspeaker variation) and within the same speaker (intraspeaker variation) that we find in the data?

It is a fact of particular historical irony that the generation of leftist American scholars from the late 1960s would form a tight-knit group of idealist revolutionaries promoting precisely idealism, i.e. mentalism, in linguistics. Chomsky and his followers were undeniably leftists engaged in fierce resistance to the Vietnam War. The, at the time, long awaited volume of Readings in Transformational Grammar, edited by Jacobs and Rosenbaum and finally published in 1970, bore the dedication: 'To the children of Vietnam 1945-19??'. But within linguistics their program was, as Labov has precisely characterized it, idealist in contrast to his own materialist stance (Labov 1987; see above). 
But then why was Labovian linguistics placed as a separate discipline, one of the two hyphen-disciplines of socio- and psycho-linguistics? Labov expressly stated that 'I have resisted the term sociolinguistics for a long time since it seems to imply that there can be a successful linguistic theory or practice which is not social' (Labov 1972 [1982]: xix).

One answer is that the publication of The Social Stratification of English in New York City in 1966 attracted the attention of empirically minded linguists trained in dialectology (e.g. Peter Trudgill, J.R. Chambers, and countless others). The prevailing climate of opinion, more or less created by the Chomskyans in debates since the publication of Chomsky's Syntactic Structures in 1957, was, however, that descriptivism, as in the case of American structuralism, was simply uninformative butterfly collecting if it was not guided by a general theory. Thus, linguistics henceforth was to be concerned with the general and abstract study of the organization of individual grammars reflecting universal principles. Only in this way could the highest goals of the enterprise of linguistics, explanatory adequacy, be fulfilled. Thus, we have a self-styled revolutionary approach centering on the individual and his or her tacit competence as revealed by introspective judgments on the limits of the language L, versus the painstaking collection of 'performance' data from a number of informants in order to reveal the hidden social structure behind apparent chaos. As Labov has recently put it:

Efforts to understand human language may be sharply divided into two distinct undertakings. Both spring from an acknowledgment that language, like the species that uses it, had a single origin. Given this perspective, one task is to discover those constant properties of language that reflect the innate biological endowment of the human species - the language faculty. The other, equally challenging, task is to discover the causes of the present diversity among the languages of the world. (Labov 2010a: 4)

The burning question lurking behind this formula of a sharp division is whether the two kinds of study could in fact be united, either as a materialist or an idealist endeavor. The jury is still out on that.

\section{WHAT IS A LINGUISTIC FACT?}

One of the differences between an idealist (Murray 1994: Chapter 9) and a materialist conception of language has to do with data, i.e. the issue of which data constitutes a linguistic fact. Like all other facts, linguistic facts must be fixed or permanent entities, so that they allow retrieval, inspection, questioning and evaluation. When linguistics at the beginning of the 19th century was founded as a science, the only available permanent data were written. This tallied with the historical nature of the enterprise. The aim was to establish first the family connections between languages and genealogical relationships among languages (Collinge 1995). This led to the need for an idealized standard, e.g. 
the Greek or the Old Icelandic language, represented with a capital 'L' (although the earliest documents showed clear variation; Berg 2014). This tallied all too well with the Herderian notion of an essential nexus of language, ethnicity and culture, an idealist notion of a language if ever there was one.

The antidote to Herderian idealism was the irreversibly materialist character of sound, cf. the famous quote by Karl Marx and Friedrich Engels from The German Ideology:

From the start the 'spirit' is afflicted with the curse of being 'burdened' with matter, which here makes its appearance in the form of agitated layers of air, sounds, in short, of language. (Marx and Engels 1845-1846: 11)

But phonetic analysis developed only slowly until it became the focus with the neogrammarians in the 1860s. Shortly before, Schleicher had proposed to go beyond the oldest attested facts and actually construct the posited Indo-European Ursprache. Schleicher's (re)constructions were all marked with an asterisk (*) since they were unattested forms. This is then the unstable compromise reached by the Neogrammarian theoretician par excellence, Hermann Paul, and treated at length by Weinreich, Labov and Herzog: a methodological focus on sound changes coupled with an idealist conception of language.

The distinction between a descriptive linguistics and a theoretical one was the cornerstone of the so-called Chomskyan revolution (Murray 1994). The revolution changed linguistic practice from inductive descriptivism to model building based on, inter alia, non-attested facts (Ruwet 1968). Idealist approaches have consistently favored data drawn from the linguist him- or herself. The attested facts were/are the utterances which could be agreed upon as possible within the language L. The non-attested facts - which inherited the Schleicherian asterisk - were now supposedly non-possible utterances. In order to be able to grasp the inner form of the language $\mathrm{L}$, we have to stipulate what is outside the language L. And no amount of attention to what people actually utter will be of any assistance in this quest, precisely because impossible utterances will never be uttered. Hence, we have to hypothesize; hence, the asterisks.

In addition to introspective data, however, the Chomskyan revolution added a new type of behavioral data, i.e. judgments about which sentences are impossible, marginal, or questionable and the collection of such judgmental data has been progressively refined (cf. Sprouse, Schütze and Almeida 2013). We now have access to principled methods of testing whether speakers accept or reject a given set of utterances (and we even have convincing evidence now that such judgmental data need not square with behavioral data from the same speakers; Buchstaller and Corrigan 2011).

Labov clearly states that introspective data or intuitions about language have formed the basis for much of linguistics because in very many cases no members of speech communities, not even linguists, disagree about whether a given sentence is a possible utterance or not (Labov 1975: 79). Matters become 
more involved when we reach levels of fine-grainedness which have been singled out for attention one way or the other. Here intuitions fail, or in Labov's words: 'very few linguists are interested in grammar which is universal but wrong' (1975: 77).

Newmeyer (2013: 80-81) recently addressed the question of why so many linguists do not avail themselves of the linguistic resources of ordinary speakers and answers that this is partly due to the small size of many of the corpora that are used. He further argues that if corpora get large enough, they may actually be used as data. This stance is a very recent one and may not be universally accepted since, even if there were large enough (speech recording) corpora available, robustly Chomskyan linguists do not see these observational data as an asset because:

a. they do not readily permit immediate comparison and analysis of various syntactic variants relevant for theoretical considerations;

b. they do not always show up in interaction with other relevant syntactic variables predicted by theoretical concerns to do so;

c. they do not allow one to derive a scale of grammaticality concerning a given phenomenon;

d. they rarely provide complete paradigms; and

e. by definition, they have nothing to say about impossible or ungrammatical structures (Barbiers, Cornips and Kunst 2007).

However, following Newmeyers' line of argument, at least one of the objections above may be addressed - statements about the impossibility of certain constructions may be falsified: if it is in the corpus files it is by definition possible. It does not take much futurologist capacity to predict that corpora will indeed grow larger every year until even spoken language corpora are monstrously large - written language corpora have already attained this status. Hence, the expansion of the storing capacity of computers will be instrumental in bringing about an empirical turn in the study of language on a par with that of the tape recorder for the study of speech.

But the effects will not necessarily be that the theory of language directing such an empirical turn will be a variationist or even a broadly sociolinguistic one. The most likely outcome is rather that of a descriptive, inductive approach based on traditional categories such as parts of speech and neglecting to contextualize results in any other way than statistically. The sheer immensity of numbers is supposed to make up for the loss of theoretical innovation.

\section{THE VARIABLE RULE AND QUANTIFICATION: PHONOCENTRISM AND ITS CONSEQUENCES}

One of Labov's major contributions to general linguistic theory, although not taken up by Chomskyan linguistics (see later section 4), was the concept of the variable rule and quantification of the data. Labov argued that: 
The ability of human beings to accept, preserve, and interpret rules with variable constraints is clearly an important aspect of their linguistic competence or language. But no one is aware of this competence, and there are no intuitive judgments accessible to reveal it to us. Instead naive perceptions of our own and others' behavior is usually categorical, and only careful study of language in use will demonstrate the existence of this capacity to operate with variable rules. (Labov 1972: 226)

Labov introduced the concept of the variable rule as an extension of the optional rules in Chomskyan theory to include social and stylistic variation in language descriptions. A résumé of the process could be as follows (taken from Cornips and Corrigan 2005a and references cited there): the first aim is to identify a representative sample of speakers and to record them under reasonably controlled conditions. After that, systematic analysis of a substantial quantity of the data takes place. Second, the identification of tokens, i.e. syntactic variants, for example a structure without copula BE and a variant with copula BE must be specified by the Principle of Accountability, that is, the total number of occurrences and the envelope of potential occurrences, i.e. the range between 0 and 100 percent in the variable environment, must be noted (Weinreich, Labov and Herzog 1968: 70). This principle guarantees that the entire range of variability between presence of copula BE 'I was small' and its absence 'He fast in everything he do' in the data will be dealt with (cf. Labov 1969: 717, for the examples).

In addition, the Synonymy Principle presupposes that tokens which have been identified as variants, i.e. 'I was small' and 'He fast', are indeed equivalent with regard to referential meaning; i.e. "alternate ways of saying "the same" thing' (Labov 1972: 118). The final objective is then to use the resultant figures in a sociolinguistic analysis of the data to classify linguistic and social factors in the environment which affect the distribution of variants.

The definition of the sociolinguistic variable fits the conditions of phonetics perfectly: on the one hand, the definition of the sociolinguistic variable respects structuralist principles differentiating phonemes by precisely delimiting which differences make a difference. On the other hand, the variants carry no cognitive but social meaning and thus are duly noted.

However, it is highly debatable whether the notion of the sociolinguistic variable may be exported unchanged to other systems, viz. syntactic and obviously - semantic ones. Thus, instead of studying the social life of signs (the original definition of Saussurean semiotics), variationist sociolinguists limit themselves to studying only the expression side of the sign. When reading through the majestic three volumes on the principles of linguistic change by Labov, it becomes surprisingly obvious that they treat only sound change. But sound change will have an intricate connection to morphological change, syntactic change and even pragmatic change and changes in genres and discourse structures. Thus, the very definition of the centerpiece of 
sociolinguistics has to be revised in order for it to take center stage in a broader study of language change as changes within subsystems and the repercussions of these changes for other parts of the general system (see section 6).

\subsection{Problems with the syntactic variable}

The variationist sociolinguistics model thus assumes that the human language faculty accommodates and continuously generates language variation and change, and that the workings of grammar may have a quantitative and noncategorical, i.e. variable, component. However, although variationist sociolinguistics still maintains the methodological practices as outlined above, it in fact rarely uses the concept of variable rules any longer (Fasold 1991) due to problems related to semantic and pragmatic conditioning of the variants to be identified.

The following problems arise. If we take equivalence of cognitive meaning as the guiding principle, operationalization in syntax seems fairly unproblematic when we are concerned with 'low level' morphological variation such as the was/were variation as in example (1) from Buckie English (Adger and Smith 2005: 156):

(1) a. I thocht you were a diver or something

b. I thocht you was a scuba diver

Problems arise, however, in the case of so-called 'high' level variables (cf. Cornips and Corrigan 2005a), for obvious frequency problems are compounded by issues relating to pragmatic and semantic conditioning. This is the case with the remote present perfect BIN in African American Vernacular English (Labov 2012: 60):

(2) She BIN married

Labov reports that Rickford (1975) found that white listeners interpret (2) as related to (3) with the contracted auxiliary has:

(3) She's been married

However, 23 out of 25 African American respondents report that (2) is not related to (3) but has different combinations of meanings such as:

- This statement is true.

- It has been true for a long time.

- It is still true.

Labov (2012: 60) noted that the workings of this grammatical feature 'come from observations of social interaction. In most uses of BIN, it is obvious that it cannot be derived by deletion of have or has'. Labov concluded that the two groups of speakers - African American respondents and white 
listeners - seem to hold contrasting views as to which variable BIN should be assigned to - if any.

Theoretical discussion on the use of the concept of the sociolinguistic variable in syntax took place at the end of the seventies and early eighties of the former century 'in a developmental phase when its definitions were being refined and improvements to methodology ongoing' (Tagliamonte 2006: 76). Since that period, problems of the sociolinguistic, syntactic variable seem to have been solved pragmatically; that is, the data and researchers' deep linguistic knowledge of the investigated community guide which elements in what contexts can be identified as variants.

Function-based approaches have already provided a number of examples of how to study sociolinguistic variables where variants may differ in meaning (Cameron and Schwenter 2013). The more one uses a functional line of thinking the more one will end up investigating semantic variation. Thus, the real challenge is to get to grips with variation which does indeed involve semantics, i.e. to find the envelope of semantic variation.

Another approach is that of Poplack and her group (e.g. Poplack and Dion 2009). In Poplack's studies of diachronic and synchronic variation in syntax, variables are identified as forms-with-interpretations (the French subjunctive) or as notional types (future temporal reference) and the conditions for variation are identified as both pertaining to interpretations and speaker characteristics as well as a number of grammatical constraints. Results are then given as variation in the constraints.

In the generative framework, variants may be identified on the basis of whether they are structurally related, i.e. hypothesized to be brought about by a chosen value of a parameter setting (Cornips 1998; Buchstaller and Corrigan 2011; Zanuttini and Horn 2014). A famous example in the generative literature is that in English the lexical verb smokes appears to the right of the adverb never as in (4a), while (4b) shows that the verb cannot appear to the left of never (Tortora 2014).

(4) a. Mary never smokes

b. *Mary smokes never

As Tortora (2014) notes, the contrast in (5) in which a Yes-No question exhibits the phenomenon of Do-support, seems on the face of it to be unrelated to the contrast in (4). But it is hypothesized to be so: the contrasts in both (4) and (5) reveal that the lexical verb in English can never move to the left of an adverb like never in (4) or to the most left position in a Yes-No question:

(5) a. Does Mary smoke?

b. *Smokes Mary?

Therefore, (4a) and (5a) may be taken as deeply syntactically related although the former contains a negation and the latter a Yes-No question. So, from a 
theoretical point of view, grammatical constraints on variation in structures like (4) would predictably also be found in constructions such as (5). Studies taking a socio-syntax approach may find good cues for deciding which variants are syntactically related (Cornips and Corrigan 2005a, 2005b) in the generative literature.

\section{MACROVARIATION VERSUS MICROVARIATION}

In this section, we will show that Labovian themes have consistently been raised and addressed in a small subsection of writings within a recent Chomskyan paradigm: micro-variation studies. Micro-variation takes an interest in dialect data and, as such, has a solid empirical basis, while addressing precisely the problem of inter- and intra-individual variation. We will show how Labovian insights and methods have seeped into Chomskyan theorizing and - primarily - practices.

The framework of generative syntax strives to reach a universalist goal; it may also be described as an 'internalist' framework that conceives of 'Grammar' as having no external existence (Cornips and Corrigan 2005a). Its essence is "to characterize what a "possible human language" might be and to provide formal grammars of individual languages' (Newmeyer 2013: 61). The proposed model of an individual's 'knowledge of language' or competence - 'Universal Grammar' (UG) - is the product of this characterization and specifies the limits within which all languages function (Newmeyer 2013: 62).

From a generative perspective, variation may be taken as brought about by different properties of functional heads (for instance aspect or tense), so that variation is always the output of differences within abstract grammatical systems (cf. Cornips 1998; Cornips and Corrigan 2005a). The relevant differences are, from this point of view, differences between individual grammars that belong to typologically different languages.

In contrast, micro-variation is concerned with the comparison and examination of grammatical systems of closely related language varieties, e.g. Danish, Swedish, Norwegian and Icelandic, or even dialects of the 'same' language, e.g. dialects of Dutch. Recently, micro-variation studies have even included intra-speaker variation (Labovian style variation) as part of linguistic competence in general; although the integration between empirical facts and linguistic analysis remains problematic (Tortora 2014).

Moreover, scholars from the micro-variation tradition also start to ask whether even sociolinguistic factors and measures of frequency may have to be integrated in their studies. Barbiers (2013: 923) notes that,

in recent versions of the minimalist program linguistic competence is reduced to a minimum and the possibility is left open that some of the universal building principles are not specific to the domain of linguistics and/or determined by interface requirements. 
Whether this refers to an integration of UG into general cognition or to extralinguistic factors is a moot point - but it certainly is an opening.

Labov's scholarly impact on general syntactic macro-variation theory is almost zero; witness the absence of almost any references to his work in the various handbooks of generative syntactic theory of recent decade(s): Handbook of Contemporary Syntactic Theory (2001); The Oxford Handbook of Comparative Syntax (2005); The Blackwell Companion to Syntax, Volumes I-V (2006); The Cambridge Handbook of Generative Syntax (2013); The Routledge Handbook of Syntax (2014); and Syntax - Theory and Analysis (2015). Notable exceptions are Kroch (2001) and Joseph (2001).

However, Labov's scholarly impact on generative micro-variation studies is clearly established and even increasing in two ways. Labov's (1972) pioneering study about negative concord in African American English in New York is taken up in recent micro-variation studies. Another impact is to be found in methodology: the recent creation of dialect atlas maps produced by generative researchers.

\subsection{Dialect atlas maps}

The intention of micro-variation studies is to provide a solid empirical basis for studying the minimal directions in which dialects can vary and which syntactic properties are parametrically related. On the one hand, this aim requires the examination of sets of very closely related varieties which only differ minimally from one another in syntax. On the other hand, both finegrained data and a huge dataset are needed to make the next step towards understanding the syntax of natural language (Barbiers 2008: 3-4).

But how do we get access to such data? Here, we again notice that slowly but surely Labovian methods seep into Chomskyan linguistic practice. A considerable number of dialect syntax atlas projects have been undertaken that rely on the elicitation of syntactic acceptability judgments from a sample of speakers in a large geographical area. This constitutes a renewal of geographical linguistics in that it combines the methodology of sociolinguistics (a large set of socially characterized informants) with the aspirations of generative syntacticians to show that not only usage data but also carefully controlled judgment data vary with geography. Pioneering insights from Labov (1975, 1996) were taken into consideration in data collection: you cannot go directly from judgment to use since a speaker may judge a certain form to be completely unacceptable, but nevertheless use it in everyday conversation (Labov 1972). Thus, the role of linguistic field work has become central to the endeavor, and the procedures through which data are elicited and ordered are truly akin to sociolinguistic practices (Cornips and Poletto 2005).

It is a matter of some interest in this connection to note the difference between the Atlas of North American English (Labov, Ash and Boberg 2006) and the atlases described above. The North American Atlas is characteristically 
concerned with, as the subtitle reads: Phonetics, Phonology and Sound Change, and it approaches consensus on a broader range of field methods from the variationist side: instead of face-to-face sociolinguistic interviews, we have 30 to 45-minute telephone conversations according to a strict format. In this way, faster and better coverage is accomplished. ${ }^{2}$

In sum, micro-variation studies, dialect atlas projects, and recent developments in linguistic disciplines such as usage-based and cognitive linguistics (cf. e.g. Geeraerts and Kristiansen 2015) have gradually eroded the otherwise firm basis for theoretical linguistics of introspection. Even Newmeyer (2013: 750) mentions Labov's (1972: 199) 'painfully obvious conclusion ... that linguists cannot continue to produce theory and data at the same time'. This is not the majority voice, however; though such insights have been with sociolinguists for half a century already.

\subsection{Coda: So what is NOT a linguistic fact?}

The lesson learnt from Labov is that a linguistic fact is an empirical fact that can be observed in social interaction and recorded in spoken interactions and that 'unsupported inquiries into speakers' introspections are not sufficient to describe the state of the language' (Labov 1996: 100). Labovian linguists do not see intuitions or introspection of the linguist as an asset because the theorist:

1. may remain unaware of the considerable degree of variation existing between individuals who perceive themselves as belonging to the same network, speech community or community of practice (Cornips and Corrigan 2005a);

2. finds some types of variation irrelevant for the theoretical proposal s/he is developing - or even worse: detrimental. A clear example is the phenomenon of double complementizers in Dutch dialects and so-called substandard Dutch that was considered irrelevant within certain stages of theory-constructing (Goeman 1980: 291);

3. may bias his or her intuitions in favor of his or her theory-building (Newmeyer 2013: 75).

Thus, the question of what constitutes a linguistic fact is certainly not only a methodological issue.

\section{WHAT A (SOCIO)LINGUISTIC THEORY SHOULD ADDRESS: PUTTING THE CHOMSKYAN FORMULA BACK ON ITS FEET ${ }^{3}$}

As discussed until now in this paper, and in the rest of this special issue, William Labov has contributed a set of generalizations and insights, firmly based on data collected and analyzed by methods developed by Labov himself, into how language varies and changes, in particular as to sound change. But we have to ask more from a general linguistic theory, i.e. a theory of language. 
No amount of methodological renewal will give us a sociolinguistic alternative to the universalistic ideas still extant. We propose instead that one way to progress is not to dismiss Chomsky but to learn from his idealism, viz. to reverse the Chomskyan formula so famously expressed in the opening pages of the Aspects of the Theory of Syntax:

Linguistic theory is concerned primarily with an ideal speaker-listener, in a completely homogeneous speech community, who knows its language perfectly and is unaffected by such grammatically irrelevant conditions as memory limitations, distractions, shifts of attention and interest, and errors (random or characteristic) in applying his knowledge of the language in actual performance. (Chomsky 1965: 3)

If we systematically dismantle this view of theory we get at least the following:

- an ideal speaker > actual speakers (cf. Joseph 1992);

- speaker-listener > difference between production and perception (cf. Labov 2008);

- homogeneous speech community > heterogeneous speech community;

- competence as the sole object of description > performance and competence as two sides of the same coin, cf. Hymes' communicative competence (1972: 282);

- applying his knowledge of the language in actual performance as irrelevant > letting linguistic practices take center stage.

This section takes up the challenge of being more explicit about what a general materialist linguistic theory would look like. It elaborates on the need for a broader and more encompassing sociolinguistic theory, including parts of the field which may not be seen as variationist by any standard.

The object of sociolinguistic theory has changed significantly since the publishing of Labov (1966). Significant changes include increasing numbers of people who circulate and are engaged in various strategies of localityproduction here, there and in-between or in multiple places simultaneously. This will alter relationships between people, the way groups may claim linguistic resources as 'theirs', the role the nation-state and national institutions plays in regulating people's linguistic practices and/or in defining their local and social identities. Any specific attachment of people to place should not be taken for granted, but studied as so many questions about the emergence and functioning of language, cultures, and identities (Mazzucato 2004). A future sociolinguistics cannot assume fixed links between specific languages or language varieties and specific (sub)communities and/or social categories without the cost of excluding relevant informants. Kerswill (1993: 55 ) noted that Labov in his study of New York excluded people who had arrived after the age of eight and in doing so chose not to picture the speech community of New York but rather the language of those inhabitants who were native to 
the city - regardless of how many percent of the total population they represented (see further in Britain 2013: 488).

An all-encompassing sociolinguistic theory is in need of a greater emphasis on shifting and multiple group membership, as well as ambiguous or uncertain group membership (Cornips and de Rooij 2013). As Cornips and de Rooij (2013: 159) note: 'multiple, shifting and ambiguous identities are the hallmark of human social life, especially in contemporary societies.' Such significant changes in the way linguistic resources and linguistic repertoires are used are, however, only part of the challenge of fitting theory to new conditions, albeit crucial enough. Below is the outline of how a materialist Labovian alternative to Chomskyan theory could be developed. We make use of the seven-layered model already presented briefly in the introduction but address only the five levels of theory.

\section{3rd level - THEORY 1: Ordering of theory laden percepts from a specific point of view}

The sociolinguistic variable has been defined as covering different ways to communicate the same content cognitively, hence the need for semantic equivalence of variants. But a more comprehensive approach calls for a definition of the variable as any way to use linguistic resources which makes a social difference, irrespective of whether cognitive semantics is held constant. Thus, the sociolinguistic variable is actually a linguistic variable and may be found at all levels of language from pragmatics through lexical semantics and to phonology. This gives rise to a crucial methodological challenge, viz. the definition of the envelope of variation. Defining the envelope of variation is, from this perspective, the primary task of the linguist and that entails precisely delimiting what is constant (if anything) and what is variable; the two sides of language structure and use are two sides of the same piece of paper, to borrow a metaphor from Saussure.

When the patterns of variation are found on the basis of massive coverage of the language use of the group, speech community or even individuals under study, the next important question to address is what social meaning the variation has, if any. This may be answered using anthropological methods designed to disclose how members use it in their day-to-day performance of identities (Eckert 2012). Finally, studies of how linguistic variables are perceived by the community, group or individual may be carried out using the methods designed by Tore Kristiansen (2009) to get at both consciously offered and unconsciously offered language attitudes.

\section{4th level - THEORY 2: Discipline specific theory, e.g. a sociolinguistic theory of language change}

A theory of language change cannot and should not be divorced from a theory of possible language states. The relative weight of 'structure' and 'social forces' 
in language change simply cannot be addressed if the two traditions of study do not agree on the terms of a comparison. Antoine Meillet has already posed the very pertinent question of why, if all the Indo-European languages stem from one root, they actually developed so differently. This is a very good question, and one that cannot be answered by separating the study of language systems from the study of language change. A break with structuralism does not, however, entail discarding structuration as a force in language communities; language is structured because use has hardened into structure. And the opposition between 'structure' and 'social forces' is not as watertight as suggested in the literature anyway. According to Muysken (1999: 72, 2000: 41-43), the cognitive abilities that shape structure determine the constraints found in language use; whereas the norms created within (groups of) speakers make structure coherent. Thus, it is untenable to picture 'grammar' as merely a transparent representation of inner mental events, since language is one of the most important media through which social acts are accomplished (cf. Cornips 2015). Thus, the norms developed by (groups of) speakers may influence structure, etc. But structure is fuzzy at all its edges and is constantly under attack by erosion and the changing functions of language use.

Furthermore, there is the question of the object of linguistic description in another sense: (socio)linguists should sharply differentiate studies of how a specific 'language' is used by the individual (idiolectal grammars), from studies of how the individual uses all those linguistic resources she or he has at her (or his) disposal to cope with her or his everyday life, i.e. integrating more or less intimate knowledge of features associated with a number of languages. This should again be separated from the study of linguistic resources used by one or more communicating groups (e.g. Labov and Harris 1986) and finally again from the study of how speech communities make use of various linguistic resources for various purposes. When in the future we study a city like New York, the study will hopefully include the problem of which linguistic resources are used by which (more or less permanent) inhabitants of the community for which purposes. Such a future study will be possible precisely because Labov (1966) laid the foundation for it.

\section{5th level - THEORY 3: Superordinate, but still object-specific, theory, e.g. a structuralist theory of language}

To encompass all of linguistics, a materialist theory has to perform internal integration. By internal integration we mean that any linguistic theory has to encompass the whole of language both spoken and written and all the mixed forms developed for and in various social media, and all language practices in situated contexts. If a sociolinguistic theory of language is to compete with other candidates for coverage, it would seem obvious that usage-based theories of the lexicon (Geeraerts 2010: 249ff.), studies of universal (but culturally variable) pragmatic phenomena such as e.g. politeness, studies of interaction 
and the study of discourse in general (e.g. Labov and Fanshel 1977) should be thought of as integrated parts of a general (socio)linguistic theory (cf. also Muysken 2005, 2015) - and modified accordingly. Such a theory would have to specify how variation and change related to speaker characterizations, speaker agency, speaker identifications, cultural context and societal forces in general would vary in (predictable?) ways, and it would obviously have a historical dimension. Generalizing the approach taken in the three-volume study of sound changes (Labov 1994, 2001, 2010a) to other types of changes, might give us indications of how changes in the social landscape filter through the layers of pragmatics, syntax and the lexicon in various ways (cf. Traugott and Dasher 2005), different from, yet akin to, the way sound changes are embedded in social-cultural geographies (Labov 2012). As noted above, a more general definition of the (socio)linguistic variable as a variation which makes a social difference, regardless of whether semantics is involved or not, would probably be helpful here.

A broad definition of the linguistic field would pave the way for an integration of the study of language use with the study of all kinds of ideologies and attitudes to varieties of language (Preston 2003, to appear). It would finally break the Herderian hold on linguistics such that all language features in the globalized language practices of today would be given equal weight in descriptions of language use.

\section{6th level - THEORY 4: Interdisciplinary theories valid for a whole field, e.g. a structuralist theory for all of the human sciences}

A lot of what goes on in language has a close connection to and may in ontogenesis be based on the prior acquisition of cognitive skills. Labov (2010b: 2), himself, views the human language faculty as an evolutionary development rooted in human physiology, i.e. as the capacity to perceive, reproduce and employ systematic variation and 'yielding information on speakers' relations to the addressee or audience as well as on their own social characteristics'. Information on social variation is probably stored separately, in a sociolinguistic monitor (Labov, Ash and Boberg 2006). A sociolinguistic theory has to be open to the integration of a linguistic theory into the study of a socio-culturally sensitive developmental cognitive and affective psychology. Only in this way can the study of language socialization be exploited in the construction of an account of how linguistic resources are appropriated as a part of situated practices.

Another integration, fervently wished for, concerns historical and contemporary sociology, and contemporary power structures: the demand for integration here means both embedding and reflection. It may seem absurd to posit this as a demand for a sociolinguistic theory since it seems to be obvious. Not so. The definition of speaker variables has an obvious bearing for practice, and yet we still miss a comparative sociological analysis of which factors or social forces have which linguistic effects in societies that are differently 
structured than the American ones studied by Labov. This is not only a question of finding a type of sociology that is compatible with linguistics, but also a demand for relating socialization and social structure: in which ways do social characteristics become significant for language use, and how does language usage contribute to the socialization process itself? Labov has contributed significantly to this endeavor by formulating important generalizations based on solid data from the U.S.A. (e.g. on the role of men and women in language change; Labov 1990, 2001: 294ff.), by pointing to the role of ethnicity as a sociolinguistic parameter (2001: 224ff.), and last but not least by seeking explanations of the chain shifts in North America by appealing to cultural geography (Labov 2012, 2013). What we miss is the broader comparative, indeed global picture. This may, however, be part of a bigger problem.

According to Deumert (2015), sociolinguistics is in dire need of what she calls a 'southern' theory in which southern does not refer to a geographical space but to an epistemological one. The metaphor refers quite broadly to a loosely coherent body of writing that speaks from the margins, linking questions of power, exploitation and history to the process of knowledge production. Such an anti-hegemonic theory challenges the center in that it addresses the question: how might 'who we are' - our gendered, raced and classed selves - impact on the knowledge we produce? Bourdieu's call for reflectivity echoes here.

Deumert examined the authors who have published in the Journal of Sociolinguistics between 2005 and 2014. More than 80 percent of the authors are located in either Europe or North America. We may add that many of them are native speakers and writers of English, dealing with English data. Deumert also examined the membership of the scientific committee of the Sociolinguistic Symposium for 2016: more than 90 percent of the scientific committee members are located at universities in the geographical and political North. This reflects global imbalances of resources, global biases of opportunity, recognition and power hierarchies in the geographies of knowledge, in particular sociolinguistic knowledge (cf. also Smakman 2015) but it also may bias our generalizations in ways still unknown to the sociolinguistic community (Deumert 2015). The demand for reflectivity concerns sociolinguistics 'in particular' because if any discipline should be self-critically aware of such imbalances, we would expect sociolinguistics to be first in line.

A sociolinguistic theory would give us a principled way to start a global comparative study of how, in fact, different societies shape different language practices.

\section{7th level - THEORY 5: World view formulated using traditional dichotomies, e.g. materialism vs. idealism; rationalism vs. romanticism; etc.}

Here we side with Labov's early stance, i.e. the radical incompatibility of materialist and idealist positions. Chomsky has elaborated on the structuralist 
notion of the autonomy of linguistics and even holds that the I-language is a separate innate faculty (Chomsky 2000). A materialist alternative would squarely place language in the real world of speakers (Joseph 1992) and conflicting interests. More importantly, in contrast to any Chomskyan theory a sociolinguistic theory would also have a number of external integrational obligations which link the stance taken inside linguistics to various other disciplines.

As we hinted at earlier, we do not see the two sides of language, one based on the biological endowment of the species and one practiced in speech communities (or other (self-)organizations of individuals) as separate. On the contrary, the link between them is (biological and social) evolution. A sociolinguistic theory has to take note of the fact that language as a phenomenon has developed along with humankind. Language as a practice must have been shaped by the long period during which humans lived as hunter-gatherers, and investigation into this process will give us relevant pieces of the puzzle of what is going on today. And at the other end of evolution, social evolution, we need to investigate how presentday media coverage and media consumption create new opportunities for linguistic resources to be selected, imitated, adapted, appropriated and recirculated (Rigney 2005: 16, quoting Foucault 1969: 156-157; see also Stuart-Smith et al. 2013).

An evolutionary view of the interplay of linguistic resources and modes of production and consumption has to sharpen or problematize the uniformitarian principle (Labov 1994: 21ff.) as an analytic tool.

\section{CONCLUSION}

In this paper we have tried to answer the question of Labov's contribution to general linguistic theory and of how he has influenced the theoretical character of linguistics as a whole. We have argued that Labovian insights and methods have gradually seeped into Chomskyan theorizing and - primarily practices regarding micro-variation, that is, the micro-syntactic enterprise of comparing minimal differences between dialects within a language and the phenomenon of intra-individual variation. The central Labovian notion of variation has made its way into mainstream theoretical linguistics: both Labov's ideas on (1) how to elicit dialect data and (2) the sociolinguistic variationist knowledge about minimal dialect differences within a language. We phrased his influence on the micro-variation enterprise as the gradual empirification of armchair linguistics under the pressure of linguistic evidence. Moreover, we presented a layered model of the levels of theory to outline a more encompassing materialist theory of language. We have argued that the very definition of the object of sociolinguistics has to change in order for the discipline to take center stage in a broader study of change.

If, at some point in the future, we may venture an answer to the eternal question of why that now? (the proverbial actuation problem) at the level of both 
language structure and linguistic interaction, and at the level of the individual, aggregated groups and societies, it will be because an integrated theory of variation and change has amassed data from all the areas we have pointed to by the demands for integration. In this we are following the lead of William Labov, as we read him.

Though the two contemporary currents of theoretical (Chomskyan) and variational (Labovian) linguistics have in fact gradually moved closer such that practices and issues from variationist sociolinguistics have come to be used and addressed also by theoretical linguists, albeit not as part of a theoretical reinterpretation of their theoretical foundations but as an extension of the remit of linguistic interaction with real world data, no theoretical integration has issued from this encounter. This is, we argue, because the two currents are incompatible. The full potential of Labovian linguistics can only be brought out by extending its aspiration so as to become an alternative to Chomskyan idealism instead of just a supplement. We are fully aware that what we have sketched in this paper is a tall order, but then again: so was the original Labovian enterprise.

\section{NOTES}

1. Neither is 'linguistics as a whole' for that matter. Our points of departure are that the first author is a variationist sociolinguist who has focussed on syntactic variables while Labov has influenced the second author's career profoundly.

2. cf. the Atlas homepage: http://www.atlas.mouton-content.com/secure/general modules/anae/unit0035/genunstart.html

3. The authors are very aware of the fact that the final chapter in a paper of this length will be hard pressed to do justice to the demands of the headline. A benevolent reader will probably be able to fill out the details. We hope to do so ourselves at a later stage.

\section{REFERENCES}

Adger, David and Jennifer Smith. 2005. Variation and the minimalist program. In Leonie Cornips and Karen P. Corrigan (eds.) Syntax and Variation: Reconciling the Biological with the Social. Amsterdam, The Netherlands/Philadelphia, Pennsylvania: John Benjamins. 149-178.

Barbiers, Sjef. 2008. Microvariation in syntactic doubling - an introduction. In Sjef Barbiers, Olaf Koeneman, Marika Lekakou and Margreet van der Ham (eds.) Microvariation in Syntactic Doubling. Bingley, U.K.: Emerald group. 1-34.

Barbiers, Sjef. 2013. Microsyntactic variation. In Marcel den Dikken (ed.) The Cambridge Handbook of Generative Syntax. Cambridge, U.K.: Cambridge University Press. 899-926.

Barbiers, Sjef, Leonie Cornips and Jan-Pieter Kunst. 2007. The syntactic atlas of the Dutch dialects: A corpus of elicited speech and text as an on-line dynamic atlas. In Joan B. Beal, Karen P. Corrigan and Hermann Moisl (eds.) Creating and Digitizing Language Corpora. Volume 1: Synchronic Databases. Hampshire, U.K.: Palgrave Macmillan. 54-90. 
Berg, Ivar. 2014. Om normalisert norrønt [On normalized Old Norse]. Arkiv för nordisk filologi 129: 21-54.

Britain, David. 2013. Space, diffusion and mobility. In J. K. Chambers and Natalie Schilling (eds.) The Handbook of Language Variation and Change (2nd edition). Malden, Massachusetts: Blackwell-Wiley: 471-500.

Buchstaller, Isabelle and Karen P. Corrigan. 2011. 'Judge not lest ye be judged': Exploring methods for the collection of socio-syntactic data. In Frans Gregersen, Jeffrey K. Parrott and Pia Quist (eds.) Language Variation - European Perspectives III. Amsterdam, The Netherlands/ Philadelphia, Pennsylvania: John Benjamins. 149-160.

Cameron, Richard and Scott Schwenter. 2013. Pragmatics and variationist sociolinguistics. In Robert Bayley, Richard Cameron and Ceil Lucas (eds.) The Oxford Handbook of Sociolinguistics. Oxford, U.K.: Oxford University Press. 464-483.

Chomsky, Noam. 1957. Syntactic Structures. The Hague, The Netherlands/Paris, France: Mouton Publishers.

Chomsky, Noam. 1965. Aspects of the Theory of Syntax. Cambridge, Massachusetts: The MIT Press.

Chomsky, Noam. 2000. New Horizons in the Study of Language and Mind. Cambridge, U.K.: Cambridge University Press.

Collinge, N. E. 1995. History of comparative linguistics. In E. F. K. Koerner and R. Asher (eds.) Concise History of the Language Sciences: From the Sumerians to the Cognitivists. Cambridge, U.K.: Cambridge University Press. 195-202.

Cornips, Leonie. 1998. Syntactic variation, parameters and their social distribution. Language Variation and Change 10: 1-21.

Cornips, Leonie. 2005. Variation and formal theories of syntax, Chomskian. In Keith Brown (ed.) Encyclopedia of Language \& Linguistics. Oxford, U.K.: Elsevier. 330-332.

Cornips, Leonie. 2015. The no man's land between syntax and variationist sociolinguistics: The case of idiolectal variability. In Aria Adli, Marco García García and Göz Kaufmann (eds.) Variation in Language: System- and Usage-based Approaches. Berlin, Germany: Walter de Gruyter (FRIAS LINGUAE \& LITTERAE). 147-172.

Cornips, Leonie and Karen P. Corrigan. 2005a. Convergence and divergence in grammar. In Peter Auer, Frans Hinskens and Paul Kerswill (eds.) Convergence and Divergence in European Languages. Cambridge, U.K.: Cambridge University Press. 96-134.

Cornips, Leonie and Karen P. Corrigan. 2005b. Toward an integrated approach to syntactic variation: A retrospective and prospective synopsis. In Leonie Cornips and Karen P. Corrigan (eds.) Syntax and Variation: Reconciling the Biological with the Social. Amsterdam, The Netherlands/Philadelphia, Pennsylvania: John Benjamins. 1-27.

Cornips, Leonie and Cecilia Poletto. 2005. On standardising syntactic elicitation techniques. PART I. Lingua 115: 939-957.

Cornips, Leonie and Vincent de Rooij. 2013. Selfing and othering through categories of race, place, and language among minority youths in Rotterdam, The Netherlands. In Pieter Siemund, Ingrid Gogolin, Monika E. Schulz and Julia Davydova (eds.) Multilingualism and Language Diversity in Urban Areas: Acquisition, Identities, Space, Education. Amsterdam, The Netherlands: John Benjamins. 129-164.

Deumert, Ana. 2015. Whose voice? Positionality in the development of southern theory. Talk presented at WUN (Worldwide Universities Network): One workshop: two projects. Multilingualism and Mobilities: Understanding Globalization, 15 October, University of Cape Town, South Africa. 
Eckert, Penelope. 2012. Three waves of variation study: The emergence of meaning in the study of sociolinguistic variation. Annual Review of Anthropology 41: 87-100.

Fasold, Ralph. 1991. The quiet demise of variable rules. American Speech 66: 3-21.

Foucault, Michel. 1969. L'Archéologie du savoir. Paris, France: Gallimard Press.

Geeraerts, Dirk. 2010. Theories of Lexical Semantics. Oxford, U.K.: Oxford University Press.

Geeraerts, Dirk and Gitte Kristiansen. 2015. Variationist linguistics. In Ewa Dabrowska and Dagmar Divjak (eds.) Handbook of Cognitive Linguistics (HSK39). Berlin, Germany: Walter de Gruyter. 366-388.

Goeman, Ton. 1980. Comp-Agreement? In Wim Zonneveld and Fred Weerman (eds.) Linguistics in the Netherlands 1977-1979. Dordrecht, The Netherlands: Foris Publications. 291-306.

Gregersen, Frans. 2000. God og dårlig eklekticisme [Good and bad eclecticism]. Mæhlum (ed.). Motskrift 1: 19-37.

Gregersen, Frans and Simo Køppe. 1988. Against epistemological relativism. Studies in the History and Philosophy of Science 19: 447-487.

Hymes, Dell H. 1972. On communicative competence. In John Pride and Janet Holmes (eds.) Sociolinguistics: Selected Readings. Harmondsworth, U.K.: Penguin. 269-293.

Hymes, Dell H. and John Fought. 1981. American Structuralism. The Hague, The Netherlands: Mouton.

Jacobs, Roderick A. and Peter S. Rosenbaum (eds.). 1970. Readings in English Transformational Grammar. Waltham, Massachusetts: Ginn and Company.

Joseph, Brian D. 1992. Diachronic explanation: Putting speakers back into the picture. In Garry Davis and Gregory Iverson (eds.) Explanation in Historical Linguistics. Amsterdam, the Netherlands: John Benjamins. 123-144.

Joseph, Brian D. 2001. Diachronic morphology. In Andrew Spencer and Arnold M. Zwicky (eds.) The Handbook of Morphology. Oxford, U.K.: Blackwell Publishing. 351-373.

Kerswill, Paul. 1993. Rural dialect speakers in an urban speech community: The role of dialect contact in defining a sociolinguistic concept. International Journal of Applied Linguistics 3: 33-56.

Kristiansen, Tore. 2009. The macro-level social meanings of late-modern Danish accents. Acta Linguistica Hafniensia 41: 167-192.

Kroch, Anthony. 2001. Syntactic change. In Mark Baltin and Chris Collins (eds.) The Handbook of Contemporary Syntactic Theory. Malden, Massachusetts/Oxford, U.K.: Blackwell Publishing. 700-701.

Labov, William. 1966. The Social Stratification of English in New York City. Washington, D.C.: Center for Applied Linguistics.

Labov, William. 1969. Contraction, deletion, and inherent variability of the English copula. Language 45: 715-762.

Labov, William. 1972 [1982/1991]. Sociolinguistic Patterns. Philadelphia, Pennsylvania: University of Pennsylvania Press.

Labov, William. 1975. Empirical foundations of linguistic theory. In Robert Austerlitz (ed.) The Scope of American Linguistics: Papers of the First Golden Anniversary Symposium of the Linguistic Society of America, Held at the University of Massachusetts, Amherst on July 24 and 25, 1974. Lisse, The Netherlands: The Peter de Ridder Press. 77-133.

Labov, William. 1984. Field methods of the project on linguistic change and variation. In John Baugh and Joel Sherzer (eds.) Language in Use: Readings in Sociolinguistics. Upper Saddle River, New Jersey: Prentice Hall. 28-53. 
Labov, William. 1987. Some observations on the foundation of linguistics [unpublished]. Available at http://www.ling.upenn.edu/ wlabov/Papers/Foundations.html

Labov, William. 1990. The intersection of sex and social class in the course of linguistic change. Language Variation and Change 2: 205-254.

Labov, William. 1994. Principles of Linguistic Change. Volume 1: Internal Factors. Oxford, U.K./ Cambridge, Massachusetts: Blackwell.

Labov, William. 1996. When intuitions fail (Papers from the parasession on theory and data in linguistics). Chicago Linguistics Society 32: 77-109.

Labov, William. 1998. Co-existent systems in African-American vernacular English. In Salikoko Mufwene, John Rickford, Guy Bailey and John Baugh (eds.) African-American English: Structure, History and Use. London: Routledge: 110-153.

Labov, William. 2001. Principles of Linguistic Change. Volume 2: Social Factors. Oxford U.K./ Cambridge, Massachusetts: Blackwell.

Labov, William. 2002. How I got into linguistics and what I got out of it [unpublished]. Available at http://www.ling.upenn.edu/ wlabov/HowIgot.html

Labov, William. 2008. Transmission and diffusion [unpublished]. Lectures held at the Radboud University, Nijmegen, The Netherlands.

Labov, William. 2010a. Principles of Linguistic Change, Volume 3: Cognitive and Cultural Factors. Oxford, U.K.: Wiley-Blackwell.

Labov, William. 2010b. What is to be learned? Talk presented at the 34th LAUD symposium on Cognitive Linguistics, 15-18 March, University of Koblenz-Landau, Landau, Germany.

Labov, William. 2012. Dialect Diversity in America: The Politics of Language Change. PageBarbour lectures for 2009. Charlottesville, Virginia/London: University of Virgina Press.

Labov, William. 2013. The Language of Life and Death: The Transformation of Experience in Oral Narrative. Cambridge, U.K.: Cambridge University Press.

Labov, William, Sharon Ash and Charles Boberg. 2006. The Atlas of North American English: Phonetics, Phonology and Sound Change. Berlin, Germany/New York: Mouton de Gruyter.

Labov, William and David Fanshel. 1977. Therapeutic Discourse: Psychotherapy as Conversation. New York/San Francisco, California/London: Academic Press.

Labov, William and Wendell A. Harris. 1986. De facto segregation of black and white vernaculars. In David Sankoff (ed.) Diversity and Diachrony. Amsterdam, The Netherlands: John Benjamins. 1-24.

Martinet, André. 1953 [1967]. Preface. In Uriel Weinreich Languages in Contact (5th edition). The Hague, The Netherlands: Mouton: vii-ix.

Marx, Karl and Friedrich Engels. 1845-46. A Critique of the German Ideology. Last accessed 29 October 2015 at https://www.marxists.org/archive/marx/works/download/Marx_The_ German_Ideology.pdf (German original: http://www.mlwerke.de/me/me03/me03_017. htm\#I_I)

Mazzucato, Valentina. 2004. Transcending the nation: Explorations of transnationalism as a concept and phenomenon. In Don Kalb, Wil Pansters and Hans Siebers (eds.) Globalisation and Development: Themes and Concepts in Current Research. Dordrecht, The Netherlands: Kluwer Academic Publishers. 131-162.

Murray, Stephen O. 1994. Theory Groups and the Study of Language in North America: A Social History. Amsterdam, The Netherlands: John Benjamins.

Muysken, Pieter. 1999. Talen. De Toren van Babel. Amsterdam, The Netherlands: Amsterdam University Press. 
Muysken, Pieter. 2000. Radical modularity and the possibility of sociolinguistics. Paper presented at the Sociolinguistics Symposium 2000, 27-29 April, University of the West of England, Bristol, U.K.

Muysken, Pieter. 2005. A modular approach to sociolinguistic variation in syntax. The gerund in Ecuadorian Spanish. In Leonie Cornips and Karen P. Corrigan (eds.) Syntax and Variation: Reconciling the Biological with the Social. Amsterdam, The Netherlands/Philadelphia, Pennsylvania: John Benjamins. 31-53.

Muysken, Pieter. 2015. Review of Tor A. Åfarli and Brit Mælhum (eds.) The Sociolinguistics of Grammar. In Norsk lingvistik Tidsskrift 33: 95-99.

Newmeyer, Frederick J. 2013. Goals and methods of generative syntax. Marcel den Dikken (ed.) The Cambridge Handbook of Generative Syntax. Cambridge, U.K.: Cambridge University Press. 61-92.

Poplack, Shana and Nathalie Dion. 2009. Prescription vs. praxis: The evolution of future temporal reference in French. Language 85: 557-587.

Preston, Dennis. 2010. Language, people, salience, space: Perceptual dialectology and language regard. Dialectologia 5: 87-131.

Preston, Dennis. To appear. The cognitive foundations of language regard. In D. Jaworska and E. Tomczak (eds.) Linguistic Takes on the Mind and Brain: Psycho-, Neuro- and Cognitive Perspectives. New York/Berlin, Germany: Mouton de Gruyter. Available at https:// english.okstate.edu/images/Preston_to_appear_YLMP.pdf

Rickford, John. 1975. Carrying the new wave into syntax: The case of Black English BIN. In Ralph W. Fasold and Roger W. Shuy (eds.) Analyzing Variation in Language. Washington, D.C.: Georgetown University Press. 162-183.

Rigney, Ann. 2005. Plenitude, scarcity and the circulation if cultural memory. Journal of European Studies 35: 11-28.

Ruwet, Nicolas. 1968. Introduction à la grammaire generative. (Recherches en sciences humanies 22). Paris, France: Plon.

Smakman, Dick. 2015. The Westernizing mechanisms in sociolinguistics. In Dick Smakman and Patrick Heinrich (eds.) Globalizing Sociolinguistics: Challenging and Expanding Theory. London: Routledge. 16-35.

Sprouse, Jon, Carson T. Schütze and Diogo Almeida. 2013. A comparison of informal and formal acceptability judgments using a random sample from Linguistic Inquiry 2001-2010. Lingua 134. Available at http://escholarship.org/uc/item/88x529wr

Stuart-Smith, Jane, Gwilym Price, Claire Timmins and Barry Gunter. 2013. Television can be a factor in language change: Evidence from an urban dialect. Language 89: 501-536.

Tagliamonte, Sali A. 2006. Analysing Sociolinguistic Variation. Cambridge, U.K.: Cambridge University Press.

Tagliamonte, Sali A. 2015. Making Waves: The Story of Variationist Sociolinguistics. Malden, Massachusetts/Oxford, U.K.: Wiley Blackwell.

Tortora, Christina 2014. Addressing the problem of intra-speaker variation for parametric theory. In Raffaela Zanuttini and Laurence R. Horn (eds.) Micro-Syntactic Variation in North American English. Oxford, U.K.: Oxford University Press. 294-323.

Traugott, Elizabeth Closs and Richard B. Dasher. 2005. Regularity in Semantic Change. (Cambridge Studies in Linguistics 97). Cambridge, U.K.: Cambridge University Press.

Weinreich, Uriel. 1953 [1967]. Languages in Contact (5th edition). The Hague, The Netherlands: Mouton. 
Weinreich, Uriel, William Labov and Marvin Herzog. 1968. Empirical foundations for a theory of language change. In Winfred P. Lehmann and Yakov Malkiel (eds.) Directions for Historical Linguistics. Austin, Texas: University of Texas Press. 95-198.

Zanuttini, Raffaela and Laurence R. Horn (eds.). 2014. Micro-Syntactic Variation in North American English. Oxford, U.K.: Oxford University Press.

Address correspondence to:

Leonie Cornips

Meertens Instituut \& Maastricht University

Oudezijds Achterburgwal 185

P.O. Box 10855

1001 EW Amsterdam

The Netherlands

leonie.cornips@meertens.knaw.nl 